\title{
A Kurdish Folio on the Marriage*
}

Mustafa Dehqan ${ }^{1}$

Received: May 12, 2016 Reviewed: June 5, 2016 Accepted: July 28, 2016

\begin{abstract}
In order to secure itself and to ensure people's interests and freedom of action every society has made a set of rules for marriage. The minor differences between Islamic and Kurdish marriage suggest that sharī' $a$ did not undergo a major revision during its transmission to the Kurds ${ }^{\mathrm{i}}$. As an Islamic form, the Kurdish marriage system is clearly derived from Qur'ān and sunna, providing a system for the preservation of its values and society. It does not mean of course that there is no any difference between Kurdish and Islamic marriage. The Kurdish system as a whole is sometimes (and only sometimes) based on a conception of tribal order which again sometimes makes no precise reference to all Islamic values. Sometimes they are impressed by their own local customs as wellii. This note presents a unique Kurdish folio on the marriage, divorce, and unified return. It provides the edition and English translation of the folio.
\end{abstract}

Keywords: Kurds, Marriage, Islam

$\underline{\text { Recommended citation: }}$

Dehqan, M. (2016). A Kurdish folio on the marriage. International Journal of Kurdish Studies 2 (2), 37 - 41.

\footnotetext{
${ }^{*}$ My special appreciation should go to Andrew J. Bush for his very useful comments on the first draft of this brief note.

1 Independent researcher, E-mail: mustafadehqan@yahoo.com
} 


\section{INTRODUCTION}

There are many Islamic marriage contracts ${ }^{\mathrm{iii}}$. The text that will appear in this brief note is among the treasures of this written tradition. But it is more than that. It is the inheritance of both Kurds and Muslims.

i) Traditional Islam regarded the marriage (nikāh) as a contract between bride's father or her legal guardian (walī) and the prospective husband. The shari ' $a$ law usually gives the guarantee of the nuptial gift (mahr), an amount of money given to the woman by prospective husband in order to recognize the legitimacy of the marriage and the financial independence for the woman. In the first section of the text, Kurdish tribal simplicity is visible. It is most likely written by a local author, or it is recited by a local informant to the educated author of the corpus.

ii) The second section of the folio is devoted to the divorce. According to Islamic shari ' $a$, the prospective husband must pronounce the phrase 'I divorce you' to his wife three times (anti tāliqun thalāthan). As there is no waiting period ('idda) between the three $t \square a l a \overline{q s}$, it seems that the folio is from Sunni Kurdistan.

The author of the folio has differently indicated the three talāqs. Each stone was a way of controlling behaviour for the man himself. When the man throws the three stones, then his divorces would take effect. Within this context, it is possible to say that throwing stones was a way of saying something like "just as surely as I am throwing three stones, I intend to divorce you three times".

iii) If a man has divorced his wife three times, but then has a change of mind, he can not simply remarry her. The last section of the folio is on the rujü' (unified return) and shari' 'a condition on how one can marry a woman whom divorced for three times. In order to reinstate a woman to her former husband, she has to get married to another man and have sex with him at least once. A person who marries a divorced woman even for one hour in order to make it possible for her ex-husband to reinstate her is named muhallil (he who makes lawful). An indirect reference to muhallil as the punishment for those Kurdish men who divorced their wives three times is clear in the third section of the folio, but Kurdish tradition applied an exclusive and much harsher punishment for the men. It may provide a warning against unconsciousness and fury. It is very easy to divorce a woman for three times but it should be accompanied with a healthy mind and intention. The regret can not be enough to guarantee a ruju ${ }^{i v}$.

\section{Text}

The folio we are dealing with is preserved in an early eighteenth century jung. Literary sources, known as jung works, are very useful in different fields of social and historical studies. They mostly contain fragments about the cultural and literary life of the period they cover, though incidental information on Kurdish literature and history can also be included.

The present unpublished manuscript derives from Central Library of Tehran University. The MS jung 3015 contains 103 folios. The size of each folio is $21 \times 10.5 \mathrm{~cm}$. The MS is written on light brown paper. The text is written with black ink on both sides of each 
folio of the manuscript. It is written in cursive script. The script is shikasta nasta 'i $\bar{q}$, the language - southern Kurdish and Persian.

As an 11th century composition, this jung includes very important historical letters, some poems by Sūzan̄̄, Bu al-'Ajabī Jurjānī, Tārīkh Khalaf Ishāq Bayg, laments, fragments on clothes, horses etc. The author is identified as Mīr Abu al-Hasan Tāj Husaynī who was the vizier of a district of Isfahān in late 11th/17th and early 12th/18th century ${ }^{\mathrm{v}}$. According to the dīwān of Qāsim Khādim Isfahānī, he died in 1133/1721 ${ }^{\text {vi }}$.

Paper's analysis and palaeographical data allow us to date the only Kurdish folio of the manuscript by $11^{\text {th }} / 17^{\text {th }}$ century. The introductory notes of the author or a further owner of manuscript (fol.1r.) of course makes it somewhat unlikely that the folio in question really belongs to the $11^{\text {th }} / 17^{\text {th }}$ century, and it would best fit sometime between $1120 / 1708$ and 1126/1714. Based on the other sections of the jung and the scattered dates, this dating very possibly is correct. As our Kurdish folio come from the same hand and from the last sections of the corpus, it seems more likely that it is written sometime between 1124/1712 and $1126 / 1714$.

\section{Transcription}

tarz-i ‘aqd-i nikāh dar Kurdistān wa talāq dādan wa rujū‘ dar mīyān-i ānān

Huwa Allāh Ta‘ālā

tarīqa-yi 'aqd kardan-i ahl-i Kurdistān. ākhund bi pidar-i dukhtar gūyad: Mehmûd Axa! bûj kenîşkim Gul Xetta we nam bi jinîyit bi ser mihranîyey pônze tomen dam be Ehmed Axa kự-i 'Ezîm Axa be kul̦-i 'iyb wel̦-i çûpanel̦, wel̦-i gawanel̦ u kuwiŗ ļowanel. qisiyk gurûhke. agar hikāyatī rū dād ki qabūl ast. pisar gūyad: u beḷî axa kuḷi 'iyb qebûļime, bûj mobarik bû maşa'ellah. tarīqa-yi talāq-i īshān. shawhar-i zan si rīg az zamīn bar mīdārad wa mīgūyad: si tiļaxim kefteke. be çûar mezhebu ki î jine we min herame. tarīqa-yi rujū' 'i îshān. hamān zan̄̄ rā ki talāq dadihand bāyad ghiyrī ù rā bardāshta bar bālā-yi pusht-i bāmī barad ki shawhar dar zīr-i ān bāshad. jamā' namāyad. dar $\mathrm{h} \square$ ālat-i jamā' kardan tāq harakat karda, gardī ki az tāq bar sar-i shawhar mīrīzad mawjib-i salb-i [sic] jawāz ${ }^{\text {vii }}$ gardad. wa ān zan-i mutallaqa bar shawhar halāl mīshawad. wa ma‘nī-yi rujū' īn ast.

\section{Translation}

The method of marriage contract in Kurdistan, and divorce and unified return among them.

He is God, may He be exalted

The method of marriage contract of the people of Kurdistan. "Mahmūd Āghā! Say I gave you Ahmad Āghā, son of 'Azīm Āghā, my daughter, named Gul Khattā, as your wife for a nuptial gift of $15 t \bar{u} m \bar{a} n \mathrm{~s}$, with all her deficiencies, [and] before shepherds, cow- and sheep-keepers", the priest says to the daughter's father. A word of group this is. [Do declare] if any objection; so it is accepted. "And yes, sir! I accept all 
deficiencies. Say congratulations! Whatever God wills!", the son says. The method of their divorce. The woman's husband took three pebbles from [the surface of] the earth and says: "I throw my three divorces. I swear to the four schools ${ }^{2}$ that this woman is unlawful to me". The method of their unified return. Someone else should take the same woman that they have divorced to the top of a roof that the husband would be under it [and] make sexual intercourse [with her]. During the sexual intercourse, roof will move [and] the dust, which poured from the roof to the head of husband, will divest the license. And that divorced woman will be lawful to [her]

\section{REFERENCES}

Abū Zahra, Muhammad (1971). Muhādarāt fì 'Aqd al-Zawāj wa Āthāruh. Cairo: Dār al-Fikr al-'Arabī.

Barth, Fredrik (1986). Father's Brother's Daughter Marriage in Kurdistan, Journal of Anthropological Research, 42 (3), 389-96.

Dirāyatī, Mustafā (2010). Fihristwāra-yi Dastniwisht-hā-yi İrān. Tehran: Kitābkhāna, Mūza wa Markaz-i Asnād-i Majlis.

Mokri, Mohammad (1962). Le marriage chez les kurdes, L'Ethnographie, 56, 42-68.husband. And this is the meaning of unified return.

\section{Endnotes}

\footnotetext{
${ }^{\mathrm{i}}$ For a general survey on Kurdish marriage, see Mokri 1962.

ii Compare Barth 1986, where the prevalence of preferential father's brother's daughter marriage in the southern districts of Iraqi Kurdistan is discussed. Here the close family endogamy is associated with a desire to maintain family property in the face of Qur'ānic rules of inheritance.

${ }^{\text {iii }}$ See, for example, 'Aqdnāmcha, MS 3781/3, Malik Library (Tehran); Izdiwāj wa Nikāh $\square$, MS 2580/2, Waz̄̄rī Library (Yazd); and 'Aqdnāma, Doc. 9-493, National Library (Tehran).

${ }^{\text {iv }}$ For a good survey on the rules of Islamic marriage and divorce, see Abū Zahra 1971.

${ }^{\mathrm{v}}$ MS 3015, fols. 27r.-29r.; Dirāyatī, 2010: iii, 996.

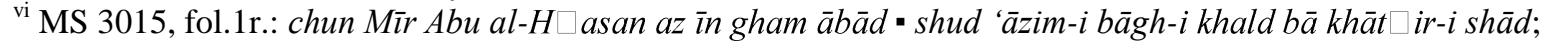
guft az piy-i tārīkh-i wafātash khādim • az tārik-i arbāb-i sukhan Tāj uftād (chronogram: 1133).

vii The reading is doubtful.
}

\footnotetext{
${ }^{2}$ The reference is to Shāfí‘ $\overline{1}, \mathrm{H} \square$ anbalī, $\mathrm{H} \square$ anafī, and Mālikī schools.
} 


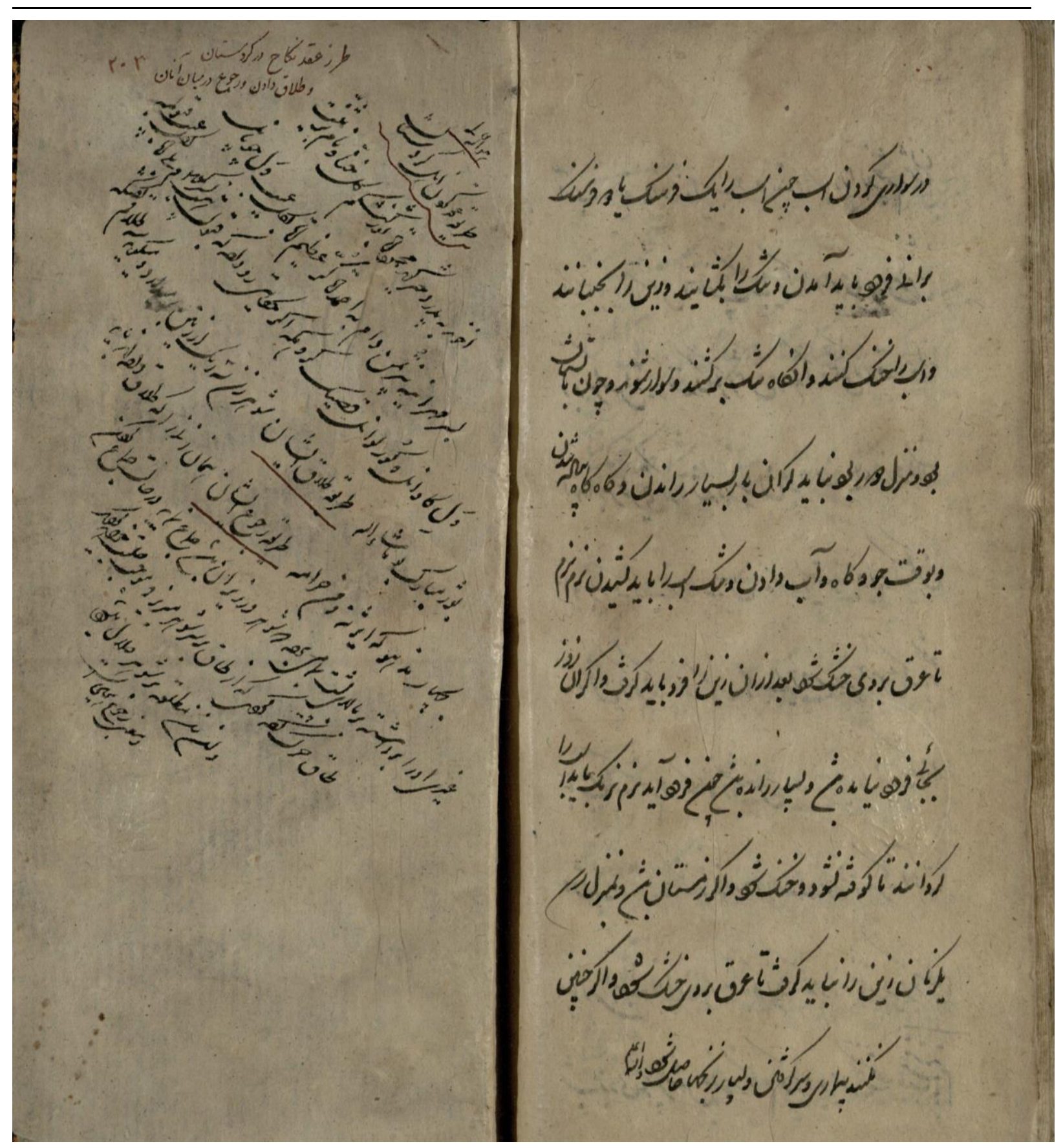

Fols.102v.-103r. 